\title{
Gastrointestinal Stromal Tumor of the Ampulla of Vater: A Narrative Review
}

\author{
Bita Geramizadeh $^{\text {a, b }} \quad$ Alireza Shojazadeh ${ }^{a}$ \\ aDepartment of Pathology, Medical School of Shiraz University, Shiraz University of Medical Sciences, Shiraz, Iran; \\ ${ }^{\text {b}}$ Transplant Research Center, Shiraz University of Medical Sciences, Shiraz, Iran
}

\section{Keywords}

Gastrointestinal stromal tumor

\begin{abstract}
Background: Gastrointestinal stromal tumor (GIST) of the ampulla of Vater is a rare occurrence. To the best of our knowledge, there has been no published review on this rare tumor in the English literature so far. Summary: In this review, we will discuss all the reported details of the published cases, including demography, clinical presentation, imaging, gross pathology and histopathology, immunohistochemical findings, treatment modalities, and outcome of cases with the diagnosis GIST from the ampulla of Vater in the last 20 years. Key Message: Twenty-five cases of GIST in the ampulla of Vater have been reported in the last 20 years in the English literature. GIST in the ampulla of Vater are usually small tumors $(<5 \mathrm{~cm})$ in middle-age patients. The majority of the patients present with lower Gl bleeding and abdominal pain. Imaging findings are not characteristic, and most of the patients without biopsy and with no histologic diagnosis were operated with the primary impression of adenocarcinoma, neuroendocrine tumor, and GIST. Perioperative tissue biopsy has been accurate in $<70 \%$ of the cases. The majority of the reported cases of GISTs in the ampulla of Vater have been low risk with spindle-cell morphology, low mitotic figures, and minimal atypia; reactive for C-KIT and
\end{abstract}

karger@karger.com www.karger.com/gat

Karger"

BOPEN ACCESS
(C) 2021 The Author(s)

Published by S. Karger AG, Basel

This article is licensed under the Creative Commons AttributionNonCommercial-NoDerivatives 4.0 International License (CC BYNC-ND) (http://www.karger.com/Services/OpenAccessLicense) Usage and distribution for commercial purposes as well as any distribution of modified material requires written permission.
DOG-1; and nonreactive for SMA, desmin, and S100. In the majority of the cases, duodenectomy with or without Whipple's operation has been performed, and most of the cases showed good prognosis.

(C) 2021 The Author(s).

Published by S. Karger AG, Basel

\section{Introduction}

Gastrointestinal stromal tumors (GISTs) are uncommon tumors of the gastrointestinal tract accounting for $1 \%$ of all gastrointestinal neoplasms. GISTs are mainly located in the stomach, and duodenal location is rare, accounting only for $<4 \%$ of all cases. Occurrence of GIST in the ampulla and periampullary region is even more uncommon [1].

To the best of our knowledge, 25 cases of ampullary GIST have been reported in the English literature so far. In this manuscript, we will review the clinicopathologic findings of all the reported ampullary GISTs [122].

\section{Materials and Methods}

Published case reports and case series in the English literature have been collected by searching in PubMed, Google, and Google Scholar in the last 20 years. The keywords for searching were "Am-
Correspondence to:

Bita Geramizadeh, geramib@gmail.com 
Table 1. Demographic findings and survival of the reported ampullary GISTs

\begin{tabular}{|c|c|c|c|c|c|c|c|c|c|}
\hline & Author & $\begin{array}{l}\text { Sex/age, } \\
\text { years }\end{array}$ & $\begin{array}{l}\text { Clinical } \\
\text { presentation }\end{array}$ & $\begin{array}{l}\text { Positive } \\
\text { laboratory } \\
\text { findings }\end{array}$ & $\begin{array}{l}\text { Tumor } \\
\text { size, } \mathrm{cm}\end{array}$ & $\begin{array}{l}\text { Mitotic } \\
\text { count, } \\
\text { /50 HPF }\end{array}$ & $\begin{array}{l}\text { Risk } \\
\text { assessment }\end{array}$ & $\begin{array}{l}\text { Surgical } \\
\text { procedure }\end{array}$ & Survival \\
\hline 1 & Kocer et al. [1] & $\mathrm{M} / 44$ & Weight loss & - & 9 & 30 & High & Whipple & $\begin{array}{l}\text { Disease free after a } \\
\text { year }\end{array}$ \\
\hline 2 & $\begin{array}{l}\text { Chariyawong and Rakvit } \\
{[2]}\end{array}$ & $\mathrm{F} / 65$ & $\begin{array}{l}\text { Lower GI } \\
\text { bleeding }\end{array}$ & - & 2.3 & 1 & Low & $\begin{array}{l}\text { Sleeve } \\
\text { duodenectomy }\end{array}$ & NR \\
\hline 3 & Mou et al. [3] & $\mathrm{M} / 56$ & Bloating & - & 1.6 & $<3$ & Low & $\begin{array}{l}\text { Endoscopic } \\
\text { mucosal dissection }\end{array}$ & $\begin{array}{l}\text { Disease free after } 3 \\
\text { months }\end{array}$ \\
\hline 4 & Kwon et al. [4] & $\mathrm{M} / 49$ & Incidental & - & 2.3 & $\mathrm{nr}$ & Low & Whipple & $\begin{array}{l}\text { Alive with no } \\
\text { recurrence }\end{array}$ \\
\hline 5 & Aksoy et al. [5] & $\mathrm{F} / 41$ & Jaundice & $\begin{array}{l}\text { Anemia } \\
\text { High ALP }\end{array}$ & 1.5 & $\mathrm{nr}$ & Low & Whipple & $\mathrm{nr}$ \\
\hline 6 & Marano et al. [6] & $\mathrm{F} / 49$ & $\begin{array}{l}\text { Lower GI } \\
\text { bleeding }\end{array}$ & High ALP & 6 & $\mathrm{nr}$ & High & Robotic resection & $\begin{array}{l}\text { Disease free after } 4 \\
\text { years }\end{array}$ \\
\hline 7 & Filippou et al. [7] & $\mathrm{F} / 65$ & Jaundice & $\begin{array}{l}\text { High AST, } \\
\text { ALT, ALP }\end{array}$ & 5 & High & Intermediate & Local resection & $\begin{array}{l}\text { Disease free after } 2 \\
\text { years }\end{array}$ \\
\hline 8 & Thavaraputta et al. [8] & $\mathrm{F} / 44$ & Abdominal pain & High ALP & 0.4 & $\mathrm{nr}$ & Low & Whipple & $\begin{array}{l}\text { Disease free after } 12 \\
\text { months }\end{array}$ \\
\hline 9 & Rotundo and Ahlawat [9] & $\mathrm{M} / 63$ & $\begin{array}{l}\text { Lower GI } \\
\text { bleeding }\end{array}$ & Anemia & 2 & $\mathrm{nr}$ & Low & Resection & $\mathrm{nr}$ \\
\hline 10 & Behranwala et al. [10] & $\mathrm{M} / 57$ & Jaundice & Anemia & 3.3 & 5 & Low & Whipple & $\begin{array}{l}\text { Recurrence after a } \\
\text { year }\end{array}$ \\
\hline 11 & Matsushita et al. [11] & $\mathrm{M} / 44$ & Jaundice & - & 8 & 90 & High & $\begin{array}{l}\text { Liver } \\
\text { transplantation }\end{array}$ & $\begin{array}{l}\text { Liver metastasis, } \\
\text { died after } 2 \text { months }\end{array}$ \\
\hline 12 & Leung et al. [12] & $\mathrm{F} / 54$ & $\begin{array}{l}\text { Lower GI } \\
\text { bleeding }\end{array}$ & Anemia & 3 & 0 & High & Local resection & Recovered well \\
\hline 13 & Liao et al. [13] & $\mathrm{F} / 63$ & Abdominal pain & - & 5 & 20 & High & $\begin{array}{l}\text { Liver } \\
\text { transplantation }\end{array}$ & $\begin{array}{l}\text { Disease free after } 13 \\
\text { years, then } \\
\text { developed liver } \\
\text { metastasis }\end{array}$ \\
\hline 14 & Bagchi et al. [14] & $\mathrm{M} / 48$ & Jaundice & Anemia & 8.8 & $>10$ & High & Whipple & $\begin{array}{l}\text { Disease free after } 7 \\
\text { months }\end{array}$ \\
\hline 15 & $\begin{array}{l}\text { Morcos and Al-Ahmad } \\
{[15]}\end{array}$ & $\mathrm{F} / 38$ & Abdominal pain & Anemia & 22 & 1 & High & Whipple & $\begin{array}{l}\text { Disease free after } 34 \\
\text { months }\end{array}$ \\
\hline 16 & Moss et al. [16] & $\mathrm{M} / 57$ & $\begin{array}{l}\text { Lower GI } \\
\text { bleeding }\end{array}$ & Anemia & 2.6 & 4 & Low & Whipple & $\begin{array}{l}\text { Alive with no } \\
\text { recurrence }\end{array}$ \\
\hline 17 & Mouaqit et al. [17] & $\mathrm{F} / 37$ & Abdominal pain & - & 7 & $\mathrm{nr}$ & High & Whipple & $\begin{array}{l}\text { Alive with no } \\
\text { recurrence }\end{array}$ \\
\hline 18 & $\begin{array}{l}\text { Candanedo-Gonzalez } \\
\text { et al. [18] }\end{array}$ & $\mathrm{F} / 61$ & Abdominal pain & Anemia & 3 & 0 & Low & Whipple & $\begin{array}{l}\text { Disease free after } 6 \\
\text { months }\end{array}$ \\
\hline 19 & Kim et al. [19] & $\mathrm{F} / 37$ & $\begin{array}{l}\text { Lower GI } \\
\text { bleeding }\end{array}$ & Anemia & 5.5 & 5 & Low & Whipple & $\mathrm{nr}$ \\
\hline 20 & Onal et al. [20] & $\mathrm{F} / 44$ & $\begin{array}{l}\text { Lower GI } \\
\text { bleeding }\end{array}$ & - & 2 & $\mathrm{nr}$ & $\mathrm{nr}$ & Surgical resection & $\mathrm{nr}$ \\
\hline
\end{tabular}


Table 1 (continued)

\begin{tabular}{|c|c|c|c|c|c|c|c|c|c|}
\hline & Author & $\begin{array}{l}\text { Sex/age, } \\
\text { years }\end{array}$ & $\begin{array}{l}\text { Clinical } \\
\text { presentation }\end{array}$ & $\begin{array}{l}\text { Positive } \\
\text { laboratory } \\
\text { findings }\end{array}$ & $\begin{array}{l}\text { Tumor } \\
\text { size, } \mathrm{cm}\end{array}$ & $\begin{array}{l}\text { Mitotic } \\
\text { count, } \\
\text { /50 HPF }\end{array}$ & $\begin{array}{l}\text { Risk } \\
\text { assessment }\end{array}$ & $\begin{array}{l}\text { Surgical } \\
\text { procedure }\end{array}$ & Survival \\
\hline 22 & & $\mathrm{~F} / 67$ & $\begin{array}{l}\text { Lower GI } \\
\text { bleeding }\end{array}$ & - & 3.3 & 1 & Low & $\begin{array}{l}\text { Partial sleeve } \\
\text { duodenectomy }\end{array}$ & $\begin{array}{l}\text { Alive with no } \\
\text { recurrence }\end{array}$ \\
\hline 24 & & $\mathrm{M} / 61$ & $\begin{array}{l}\text { Lower GI } \\
\text { bleeding }\end{array}$ & - & 2.3 & & Low & $\begin{array}{l}\text { Partial sleeve } \\
\text { duodenectomy }\end{array}$ & $\begin{array}{l}\text { Alive with no } \\
\text { recurrence }\end{array}$ \\
\hline 25 & Kobayashi et al. [22] & $\mathrm{M} / 36$ & GI bleeding & Anemia & 2.2 & 0 & Low & Whipple & $\begin{array}{l}\text { Disease free after } 1.5 \\
\text { years }\end{array}$ \\
\hline
\end{tabular}

GIST, gastrointestinal stromal tumor; ALP, alkaline phosphatase; nr, not reported.

pulla of Vater," "Periampullary," “Ampullary," "Duodenum," "Small intestine," and "Gastrointestinal stromal tumor."

It is worthy to note that the included studies have specifically mentioned the presence of tumor in the ampullary or periampullary region. Twenty-five cases were found in the English literature.

\section{Results}

Tables 1 and 2 show the clinicopathologic characteristics of these 25 reported and published cases with ampullary GIST in the English literature [1-22].

\section{Demographic Findings}

Fourteen patients were female, and 11 were male $($ male/female $=11 / 14)$. The age range was $28-67$ years with a mean of $50.5[1-22]$.

\section{Clinical Presentation}

The majority of the patients presented with lower GI bleeding either as fresh rectal bleeding or melena. One of these patients presented with unconsciousness secondary to low blood pressure and GI bleeding [22]. Other symptoms were abdominal pain in 6 and jaundice in 5 patients. Other rare gastrointestinal symptoms were also reported such as bloating [3] and weight loss [1] as the primary clinical presentation [3]. One of the patients was incidentally found during investigation and follow-up of gastric adenocarcinoma [4].
Table 2. Summary of the clinicopathologic findings of the 25 reported cases of ampullary GIST

\begin{tabular}{ll} 
Clinicopathologic findings & \\
\hline Sex $(\mathrm{F} / \mathrm{M})$ & $14 / 11$ \\
\hline Age, years & $28-67(50.5 \pm 10.7)$ \\
\hline Most common clinical presentation & Lower GI bleeding $(44 \%)$ \\
\hline Most common laboratory finding & Anemia (24\%) \\
\hline Tumor size, cm & $1.5-22(4.7 \pm 4.2)$ \\
\hline Mitotic counts, /50 HPF & $0-100(15.4 \pm 30)$ \\
\hline Most common risk group & Low (60\%) \\
\hline Outcome & $\begin{array}{l}\text { Alive with no recurrence } \\
\text { and no metastasis after 6 } \\
\text { month to } 13 \text { years } \\
(2.3 \pm 3.4 \text { years })\end{array}$
\end{tabular}

GIST, gastrointestinal stromal tumor.

\section{Laboratory Findings}

In the majority of the patients, laboratory tests were normal, except for anemia which was the most common abnormal laboratory finding. Rare isolated reports of abnormal liver function tests and elevated bilirubin, especially high alkaline phosphatase, were also reported [5-8].

Past Medical History and Other Medical Conditions

History of neurofibromatosis type 1 was reported in 3 patients [8-10]. One of the patients with neurofibroma- 
tosis and ampullary GIST had also celiac disease and pituitary adenoma [8]. Gastric cancer has been reported in 2 patients; in one, it was found 2 years prior to ampullary GIST diagnosis [4] and in the other, both GIST and gastric cancer were simultaneously diagnosed [7]. In another case, adenocarcinoma of the ampulla of Vater was reported [1]. Also, one of the patients was diagnosed to have pancreatic ductal adenocarcinoma at the time of diagnosis of GIST in the ampulla of Vater [10]. In 2 of the reported cases, simultaneous duodenal neuroendocrine tumor was also diagnosed within the duodenum $[1,8]$. Another patient had a past medical history of diverticulitis [2]. Family history in the case report by Leung et al. [12] was positive for breast cancer, colon cancer, coronary artery disease, and stroke. The patient had a history of hypertension, tachycardia, and anxiety disorder.

\section{Imaging Studies}

In $>20$ reported cases of ampullary GIST, imaging studies were reported, consisting of ultrasonography, CT scan, and MRI. The most important imaging finding was common bile duct and/or pancreatic duct dilatation. In ultrasonography, GISTs in the ampulla are hypoechoic masses. CT scan of the mass reported hypervascular uniformly or peripherally enhanced masses with or without central necrosis. Ampullary GIST is reported as a welldefined mass with pushing border and indentation of adjacent organs without significant invasion. MRI of ampullary GIST has been reported to show low signal intensity on T1-weighted images and high signal intensity on the T2-weighted image [7-15].

Main differential diagnosis by imaging modalities is adenocarcinoma of the ampulla of Vater or pancreatic ductal adenocarcinoma in the pancreatic head. The only way for the best diagnosis is histology and biopsy before surgery [10-15].

\section{Endoscopic Findings}

In 16 cases, endoscopic findings have been reported as round to oval submucosal or subserosal mass or masses with overlying mucosal ulceration arose from the duodenal wall, without intraluminal projection. Some tumors showed minimal invasion to the adjacent pancreatic head as well $[11,16]$.

In 8 cases, presurgical biopsies have been taken which was correctly diagnosed in 5 patients $[1,2,7,12,17]$, and other 3 cases were either nondiagnostic (normal mucosa) or incorrectly diagnosed as carcinoma $[2,16,17]$. In most of the patients without perioperative histology, the clinical impression has been carcinoma of the ampulla of
Vater/head of pancreas, neuroendocrine tumor, and GIST.

\section{Microscopic Findings}

Twenty-one out of 25 reported cases of GISTs in the English literature showed pure spindle-cell morphology with fascicular and storiform patterns. Only 4 cases showed focal epithelioid morphology $[1,7,18,20]$. Skenoid fibers were reported in 2 cases $[15,18]$. In the case reported by Candanedo-Gonzalez et al. [18], focal collections of skenoid fibers with osteoid-like material and focal aneurysmal bone cyst-like areas were seen. Six ampullary GISTs reported to have bizarre and atypical spindle-shaped cells $[1,7,11,14,20]$.

Most of the reported cases of ampullary GIST are categorized as low risk, that is, the number of mitosis was low $(<5 / 50 \mathrm{HPF})$, and the tumors were mostly small $(<5$ $\mathrm{cm})$. Only 5 cases have been reported with large size, that is, $>5 \mathrm{~cm}$ [1-22].

The main differential diagnosis in these cases is spindle-cell tumors of the gastrointestinal tract, mostly schwannoma, leiomyoma, leiomyosarcoma, malignant peripheral nerve sheath tumors, and desmoid tumors. Immunohistochemistry can be helpful for the definite diagnosis [10-21].

\section{Immunohistochemistry and Molecular Studies}

All the reported GISTs in the ampullary lesion were reactive with CD34. CD117 was negative in 2 cases $[2,15]$. Also, all of the reported DOG-1 were positive. Smooth muscle actin has been stained in 9 cases, and 7 of them $(77.8 \%)$ were negative and 2 were positive $[13,20]$. Desmin has been stained in 6 cases; only one has been positive, and all the other 5 cases were negative [13].

In 8 out of 9 cases with reported S100, the antibody was nonreactive, and in only 1 case, $S 100$ was positive [15]. In Liao et al.'s [13] case, they have done genetic studies, and the tumor showed KIT N822K gene mutation in exon 17.

\section{Treatment}

In 13 patients, Whipple's operation was performed. In 4 patients, duodenectomy and resection were done [7, 9, $12,14]$. In 5 patients, sleeve duodenectomy was the procedure $[2,21]$. Two patients developed liver metastasis, and liver transplantation and Whipple were the procedures to resect the tumor and the metastasis $[11,13]$.

In only 1 case endoscopic mucosal dissection was done to resect the tumor [3]. In 1 case, duodenal sparing robotic resection has been performed [6]. All of the above surgical procedures have been performed in association 
with imatinib (tyrosine kinase inhibitor) administration [1-22].

\section{Outcome}

Liver metastasis has been reported in 2 ampullary GISTs $[11,13]$. Also, lymph node metastasis has been reported in 1 case [11]. In 1 patient, local recurrence was developed [10]. All of the other 21 patients were free of any recurrence or metastasis.

\section{Conclusions}

Ampullary GIST is a rare tumor, mostly present with lower GI bleeding and small size. The imaging in this tumor is not specific, and perioperative biopsies are not so accurate (because of the submucosal location). The majority show low mitoses and are reactive with C-KIT and DOG-1. Ampullary GISTs can be treated effectively with imatinib and surgical resection. Findings of GIST in the ampulla of Vater are very similar to our previous experiences in regard to the demographic findings, pathologic characteristics, and outcome [23-25].

\section{Conflict of Interest Statement}

The authors have no conflicts of interest to declare.

\section{Funding Sources}

The authors did not receive any funding.

\section{Author Contributions}

Bita Geramizadeh: idea of the project, searching the literature, and writing the manuscript. Alireza Shojazadeh: searching the literature and writing the manuscript.

\section{References}

1 Kocer AE, Kayaselc F, Caliskan K, Ulusan S. Synchronous GIST with osteoclast-like giant cells and a well-differentiated neuroendocrine tumor in Ampula Vateri: coexistence of two extremely rare entities. Pathol Res Pract. 2007 Jul 25;203(9):667-70.

2 Chariyawong P, Rakvit A. Gastrointestinal stromal tumor at ampulla of Vater presented with upper gastrointestinal bleeding. Am J Gastroenterol. 2017;112(Suppl 1):S1556-57.

3 Mou Y, Wu C, Yi H, Liu W, Jing L, Luo R, et al. A case report: endoscopic enucleation of gastrointestinal stromal tumor of the ampulla of Vater. Clin J Gastroenterol. 2013 Jun;6(3): 198-201.

4 Kwon SH, Cha HJ, Jung SW, Kim BC, Park JS, Jeong ID, et al. A gastrointestinal stromal tumor of the duodenum masquerading as a pancreatic head tumor. World J Gastroenterol. 2007 Jun;13(24):3396-9.

5 Aksoy NH, Cevikol C, Ogüs M, Elpek GO, Gelen T. Adenocarcinoma arising in villous adenoma of the ampulla of Vater with synchronous malignant gastrointestinal stromal tumour of the duodenum: a case report. J Clin Pathol. 2004 Oct;57(10):1118-9.

6 Marano A, Allisiardi F, Perino E, Pellegrino L, Geretto P, Borghi F. Robotic treatment for large duodenal gastrointestinal stromal tumor. Ann Surg Oncol. 2020 Apr;27(4):11012.

Ampullary GIST
7 Filippou DK, Pashalidis N, Skandalakis P, Rizos S. Malignant gastrointestinal stromal tumor of the ampulla of Vater presenting with obstructive jaundice. J Postgrad Med. 2006 Jul-Sep;52(3):204-6.

8 Thavaraputta S, Graham S, Rivas Mejia AM, Lado-Abeal J. Duodenal somatostatinoma presenting as obstructive jaundice with the coexistence of a gastrointestinal stromal tumour in neurofibromatosis type 1 : a case with review of the literature. BMJ Case Rep. 2019 Jan;12(1):bcr-2018-226702.

9 Rotundo L, Ahlawat S. Severe acute gastrointestinal bleed in a patient with neurofibromatosis type 1. Gastroenterology. 2019 Feb; 156(3):e1-2.

10 Behranwala KA, Spalding D, Wotherspoon A, Fisher C, Thompson JN. Small bowel gastrointestinal stromal tumours and ampullary cancer in type 1 neurofibromatosis. World J Surg Oncol. 2004 Jan 7;2:1.

11 Matsushita M, Kobayashi Y, Kobayashi H, Nagasawa M, Sato Y, Nakamura H. A case of gastrointestinal stromal tumour of the ampulla of Vater. Dig Liver Dis. 2005 Apr;37(4): 275-7.

12 Leung K, Worni M, Galeotti J, Blazer D. A novel approach: local resection for ampullary GIST-case report and review of literature. J Gastrointest Cancer. 2017 Dec;48(4):376-78.

13 Liao W, Hu A, Zhu X, Wang W. Liver transplantation for a metastasized duodenal gastrointestinal stromal tumor: a case report and review of the literature. Int J Clin Exp Med. 2019 May;12(5):5419-25.
14 Bagchi A, Mahamine K, Nundy S, Kathuria P, Sahu P, Kumar S, et al. Periampullary gastrointestinal stromal tumor presenting with obstructive jaundice. Trop Gastroenterol. 2015 Oct-Dec;36(4):275-7.

15 Morcos B, Al-Ahmad F. A large gastrointestinal stromal tumor of the duodenum: a case report. J Med Case Rep. 2011 Sep 14;5:457.

16 Moss AC, Callery MP, Falchuk KR. Gastrointestinal [corrected] stromal tumor of the ampulla of Vater mimicking a duodenal ulcer. Clin Gastroenterol Hepatol. 2007 Oct;5(10): A26.

17 Mouaqit O, Ktaibi R, Ktaibi A, Mounim M, El malki EHO, Mohsine R, et al. A duodenal stromal tumor mimicking a pancreatic head tumor: one case report and literature review. Eur Surg. 2013 Jan 24;45(1):40-3.

18 Candanedo-Gonzalez F, Camacho-Rebollar L, Uscanga CC, Utrilla AR, Bucio ME, Rodriguez SS, et al. Gastrointestinal stromal tumor of the ampulla of Vater with osteoclastic giant cells, osteoid-like matrix deposition, and aneurysmal bone cyst-like features. Ann Diagn Pathol. 2013 Aug;17(4):372-6.

19 Kim SH, Kim JH, Baik GH, Baek I, Hahn T, Oh SO, et al. Malignant gastrointestinal stromal tumor of the ampulla of Vater: a case report. Korean J Gastroenterol. 2004 Jan;43(1): 66-70. 
20 Onal IK, Kurt M, Akdogan M, Kalkan IH, Kiremitci S, Odemis B, et al. A rare cause of upper gastrointestinal bleeding: stromal tumor of duodenum masquerading as papilla vateri. Am J Gastroenterol. 2009;104(2):535.

21 Choi SH, Park J, Kang CM, Lee WJ. Laparoscopic partial sleeve duodenectomy for the infra-ampullary gastrointestinal stromal tumors of the duodenum. World J Surg. 2018 Dec;42(12):4005-13.
22 Kobayashi M, Hirata N, Nakaji S, Shiratori T, Fujii H, Ishii E. Gastrointestinal stromal tumor of the ampulla of Vater: a case report. World J Gastroenterol. 2014 Apr 28;20(16): 4817-21.

23 Geramizadeh B, Bahador A, Ganjei-Azar P, Asadi A. Neonatal gastrointestinal stromal tumor. Report of a case and review of literature. J Pediatr Surg. 2005 Mar;40(3):572-4.
24 Geramizadeh B, Jowkar Z, Ranjbar Z. Frequency of KIT mutation in gastrointestinal stromal tumors according to histologic and immunohistochemical findings, the first report from Iran. Iran J Med Sci. 2015 Jul;40(4): $316-21$

25 Geramizadeh B, Nosrati A. Histological and immunological evaluation of gastrointestinal stromal tumors. Iran J Med Sci. 2006 Apr; 31(1):14-7. 